\title{
Aktif Öğrenmeye Dayalı Etkinliklerin Okul Öncesi Öğretmen Adaylarının Çevre Etiği Farkındalı̆̆ı, Çevre Davranışı ve Çevre Eğitimine İlişkin Özyeterliklerine Etkisi
}

\author{
The Effect of Active Learning Based Activities on the Pre-School Teacher Candidates' \\ Environmental Ethics Awareness, Environmental Behavior and Self Efficacy Related to \\ Environmental Education
}

\section{Gülfem MUŞLU KAYGISIZ* Elif BENZER ${ }^{* *}$ Canan DÍLEK EREN ${ }^{* * *}$}

\begin{abstract}
Öz
$\mathrm{Bu}$ araştırmanın amacı aktif öğrenmeye dayalı öğretimin okul öncesi öğretmen adaylarının çevre etiği farkındalıklarına, çevreye yönelik davranışlarına ve çevre eğitimi özyeterliklerine etkisinin olup olmadığını belirlemektir. Araştırma 2017-2018 öğretim yılı güz döneminde "Çevre Eğitimi ve Sürdürülebilirlik” dersi kapsamında 29 Okul öncesi öğretmen adayı ile yürütülmüştür. Araştırma verileri Çevre Etiği Farkındalık Ölçeği, Çevre Davranış Ölçeği ve Çevre Eğitimi Özyeterlik Ölçeği ile toplanmıştır. Araştırma zenginleştirilmiş desen temelinde gerçekleştirilmiştir. Karma bir özellik taşıyan bu desenin nicel kısmında zayıf deneysel desen uygulanmış ve veriler SPSS 22 programında analiz edilmiştir. Araştırma kapsamında öğretmen adaylarından çevreye ilişkin filmleri analiz etmeleri, çevre konusundaki makaleleri incelemeleri ve çevreye ilişkin geliştirdikleri etkinlikleri içeren ders sunumları yapmaları istenmiştir. Araştırmanın ön test-son test sonuçlarına göre aktif öğrenmeye dayalı etkinliklerin öğretmen adaylarının çevre etiği farkındalıklarında ve
\end{abstract}

* Dr. Öğr. Üyesi, Hasan Kalyoncu Üniversitesi Eğitim Fakültesi, E-posta: gulfem.muslu@hku.edu.tr, Orcid ID: https://orcid.org/0000-0003-3286-0454

** Doç. Dr., Marmara Üniversitesi Eğitim Fakültesi, E-posta: elif.benzer@marmara.edu.tr, Orcid ID: https://orcid.org/0000-0002-2518-768X

*** Dr. Öğr. Üyesi, Kocaeli Üniversitesi Eğitim Fakültesi, E-posta: canandilek@kocaeli.edu.tr, Orcid ID: https://orcid.org/0000-0002-7004-5066 
çevre davranışlarında anlamlı farklılık yaratmadığı; çevre eğitimi özyeterliklerinde ise olumlu yönde değişiklik oluşturduğu tespit edilmiştir.

Anahtar kelimeler: Aktif Öğrenme, Çevre davranışı, çevre etiği farkındalığı, çevre eğitimine ilişkin özyeterlik, öğretmen adayları.

\begin{abstract}
The aim of this research is to determine whether active learning-based instruction effects preschool teacher candidates' awareness of environmental ethics, environmental behaviors and environmental education self-efficacy. The study was carried out with 29 preschool teacher candidates within the scope of "Environmental Education and Sustainability" course in the Fall semester of 2017-2018 academic year. Data were obtained through Environmental Ethics Awareness Scale, Environmental Behavior Scale, and Environmental Education Self-Efficacy Scale. The research was based on triangulation design which is mixed method and quantitative part of it the research data obtained on weak experimental design study. The data were analyzed in the SPSS 22 program. In the scope of the study, teacher candidates were asked to analyze the films related to environment, to examine the articles concerning the environment, and make presentations with the activities that they developed regarding the environment. The findings of the study revealed that activities based on active learning did not make a significant difference in teacher candidates' awareness of environmental ethics and environmental behaviors, but it had positive effects on their self-efficacy in environmental education
\end{abstract}

Keywords: Active learning, environmental behavior, environmental ethics awareness, self-efficacy in environmental education, teacher candidates.

\title{
Giriş
}

Çevre; insanların sosyal ve fiziksel bütün faaliyetlerini sürdürdükleri ortamdır. Bu ortamda insanların hayatlarını sağlıklı olarak sürdürebilmeleri için çevreleri ile uyum içerisinde olmaları gerekmektedir. Bu uyumun sürekliliği ise insanların çevreye olan olumsuz etkilerini azaltmakla mümkündür. İşte tam bu noktada çevre eğitimi gereksinimi ortaya çıkmaktadır. Çevre eğitimi, insanın ekolojik çevresini tanımasını, buradaki yerini kavramasını, yaşadığı gezegenle nasıl uyum içerisinde yaşayabileceğine ilişkin görüş geliştirmesini ve etkin bir katılım için gerekli becerileri kazanmasını sağlamaktadır (Bozkurt, 2009, s.210). Çevre konusunda yeterli eğitim almayan, çevreye yönelik sorumlu davranış geliştirmeyen bireylerin çevreye bilinçli veya bilinçsiz olarak zarar vermeleri de olası görülmektedir. Bu nedenle bireylerin çevreye yönelik davranışlarının belirlenmesi (Timur ve Yılmaz, 2013) ve bu davranışların çevre yararına geliştirilmesinin önemi ortaya çıkmaktadır. Nitekim Yücel, Işıldar ve Yıldırım (2008) yaptıkları çalışmada 'çevre' konularında eğitim gören üniversite öğrencilerinin çevreci davranışlar göstermek konusunda daha duyarlı olduklarını, çevreyi koruyan davranış kalıplarını daha fazla uyguladıklarını bulmuştur.

Çevreye yönelik sorumlu davranışa sahip olmanın yanında ekosistemi oluşturan tüm varlıkların uyum ve işbirliği içinde var olabileceği bir yaşam etiğinin temeli olarak; çevre etiği kavramı karşımıza çıkmaktadır (Akkoyunlu Ertan, 1998, s.139). Genel anlamda insan ve 
doğal çevresi arasındaki ahlaki ilişkinin sistematik bir değerlendirmesi olan (Ertan, 2004) bu kavram incelendiğinde, gelişim sürecinde farklı yaklaşımların ortaya çıktığı gözlenmiştir (Özer, 2015, s.21). En eski çevre etiği yaklaşımı olan insan merkezli - antroposentrik yaklaşımından sonra canlı merkezli-biyosentrik ve çevre merkezli-ekosentrik çevre etiği yaklaşımlarının da sırayla ortaya çıktığı bilinmektedir. Antroposentrik yaklaşıma göre, diğer canlılar veya cansız varlıklar insanlara yarar sağladığı sürece değerlidir. Eğer insan için herhangi bir yararı yok ise o canlı veya cansız varlığın da herhangi bir ahlaki değeri yoktur. Biyosentrik yaklaşıma göre, canlı varlıkların değerinden, öneminden yola çıkarak çevre etiği tanımlanmaktadır. Ekosentrik yaklaşım ise ekosistemi oluşturan canlı ve cansız tüm varlıkları temel alan bakış açısıdır (Özer, 2015, s.24-26). İnsanların sahip olduğu değer sistemlerinin onların davranış ve tutumlarına da yansıyabileceğinden hareketle temelde sahip oldukları çevre etiği farkındalıklarının belirlenmesi önem arz etmektedir.

"İnsanların belirli çalışma türleri gerektiren faaliyetleri organize etme ve yürütme kapasiteleri hakkındaki yargıları” (Bandura, 1986) olarak tanımlanan öz yeterlik inancın temelinde; öğretmenlerin eğitim-öğretimle ilgili inanışlarının planlama, karar verme ve sınıf içi faaliyetlerle ilişkili olması bulunmaktadır (Pajares, 1996). Yapılan bazı araştırmalar öz yeterliği yüksek olan öğretmenlerin sınıf içi etkinlikleri bireysel farklılıkları da göz önüne alarak daha etkin bir şekilde planladıklarını ve öğrenci başarısı konusunda daha iyimser olduklarını göstermektedir (Yılmaz ve Çimen, 2008; Tschannen-Moran, WoolfolkHoy ve Hoy, 1998; Riggs ve Enochs, 1990). Öğretmenlerin sahip oldukları öz yeterlik inancının; sınıf içi faaliyetleri, alanlarına ilişkin çalışmaları ve etkili ders işleme oranlarını etkileyebileceği görüldügüünden öğretmen adaylarının da özyeterlik inançlarının tespiti ve geliştirilmesi önemli görülmektedir (Önen ve Muşlu Kaygısız, 2013).

Etkili bir çevre eğitiminin yapılabilmesi için özellikle okul öncesi dönemden itibaren çocukların belirtilen amaçlar çerçevesinde süreçlere katılmaları gerekmektedir. Bunun sağlanabilmesinde de elbette okul öncesi öğretmenlerin çevre eğitimine ilişkin niteliklerinin geliştirilmesi önemlidir. Bu nedenle özellikle eğitim süreçlerinde öğretmen adaylarının çevre eğitimine ilişkin yeterliklerinin geliştirilmesi ve bununla birlikte çevreye ilişkin var olan çeşitli bilgi ve becerilerinin de tespiti ve geliştirilmesi önemlidir. Öğretmen adaylarının çevreye ilişkin öğretim özyeterliklerinin geliştirilmesi öğretmen oldukları zaman daha etkili şekilde öğretim yapmalarına yardımcı olacaktır.

Yalçın (1993)'ın Okutan'dan aktardığına göre çevre eğitimi, "bireylerde çevre bilincinin geliştirilmesi, çevreye duyarlı, olumlu, kalıcı davranış değişikliklerinin kazandırılması ve doğal, tarihi, kültürel, sosyo-estetik değerlerin korunması, aktif katılım sağlanması ve sorunların çözümünde görev alma” şeklinde tanımlanmaktadır. Çevre eğitiminin etkililiğini arttırmak için özellikle okul öncesi dönemden itibaren çalışmaların yapılması önem arz etmektedir. Aynı gerekçe ile Milli Eğitim Bakanlığı (MEB) da çevre eğitimine yönelik çalışmalar yürütmektedir. Sancar (2005, s.11) MEB’nın, 1992 yılından itibaren okul öncesi eğitimde, özel ve resmi anaokulu sınıflarında çevre bilincinin arttırılması için çevre eğitimi ile ilgili konulara yer verilmeye başlanmasını sağlayarak, ilköğretim düzeyinde de 1995-96 eğitim ve öğretim yılından itibaren ders içeriklerinde çevre ile ilgili 
konuların yer almasını sağlayarak çevre eğitimine ilişkin girişimlerde bulunduğunu belirtmiştir. Okulöncesi programlarında çevre konularının yer alması kadar bu konuların nasıl işleneceğine yönelik iyileştirmelere de ihtiyaç duyulmaktadır. Bunun için uygulanabilecek yaklaşımlardan biri de aktif öğrenmeye dayalı etkinliklerle derslerin işlenmesidir.

Aktif öğrenme, genel anlamı ile öğrencilerin aktif olduğu öğrenme durumudur (Kalem ve Fer, 2003, s.434). Öğrenciler öğrenmenin merkezinde ve kendi öğrenmeleri ile ilgili kararları alan temel öğedirler. Bu süreçte aktif öğrenme; öğrenenin zihinsel yeteneklerini kullanarak öğrenilen bilgiler üstünde yorum yaptı̆̆ bir süreçtir (Süral, 2015). Mentiş Taş (2005)’a göre aktif öğrenme bütün öğretim kademelerinde özellikle de öğretmen eğitiminde uygulanmalıdır. Çünkü bir öğretmen adayının hizmet öncesi eğitim sürecinde içinde bulunduğu öğrenme öğretme ortamları daha sonraki meslek yaşamını şekillendirmesinde önemli bir etkendir.

Farklı örneklem gruplarıyla yapılan çalışmalar aktif öğrenmenin çevre duyarlılığı-bilinciçevreye ilişkin kavramların öğretimine etkisi gibi çeşitli değişkenler üzerinde çevre konusunda değişime neden olduğunu göstermektedir (Aydede Yalçın, 2016; Şahin, Cerrah, Saka ve Şahin, 2004; Şenel, 2010). Tüm bunlar göz önüne alındığında öğretmen adaylarının aktif öğrenme merkezli etkinliklerle çevreye ve çevre eğitimine ilişkin yeterliklerinin gelişimine katkı sağlanabilineceği düşünülmektedir. Alanyazında çevre eğitimi özyeterlik (ÇÖZ) konusunda öğretmen adayları ile yapılan bazı çalışmalara rastlanmıştır. Bu çalışmalarda; Kahyaoğlu (2001) ÇÖZ ile öğrenme stilleri arasındaki ilişkiyi, Zayimoğlu-Öztürk, Öztürk ve Şahin (2015) ÇÖZ ile çevre eğitimi dersi alma durumu arasındaki ilişkiyi, Gökmen, Ekici ve Öztürk (2012) ÇÖZ ile çeşitli betimsel değişkenler arasındaki ilişkiyi, Aydın (2008) ÇÖZ inançlarının öğretmen adaylarının sınıf-kıdem ve hayatlarına rehber olan değer yönelimlerine göre değişip değişmediğini incelemişlerdir. Ancak alan yazında okul öncesi öğretmen adaylarının ÇÖZ inceleyen ve ÇÖZ’e ilişkin gelişimlerinin tespit edilmesine yönelik yürütülen araştırmalara rastlanmamıştır.

\section{Araştırmanın Amacı}

Bireylere, doğal çevreleri ile uyum içerisinde yaşayabilmeleri ve bu uyumun sürekliliğini sağlayabilmeleri için erken çocukluktan itibaren çevre etiği farkındalığ ve çevreye ilişkin olumlu davranış kazandırılması gibi bazı özelliklerin kazandırılmış olması büyük önem arz etmektedir. Bu bir süreçtir ve bu süreçte en büyük görev öğretmenlere, özellikle de okul öncesi öğretmenlerine düşmektedir. Söz konusu özellikler açısından öğretmen adaylarının lisans eğitimleri sürecinde iyi yetiştirilmeleri gerekmektedir. Bu nedenle, araştırmada okul öncesi öğretmen adaylarının çevreye ilişkin davranışlarının, çevre etiğine ilişkin farkındalıklarının ve çevre eğitimi özyeterliklerinin geliştirilmesi için aktiföğrenme merkezli etkinlikler uygulanmışve bu etkinliklerin etkisi araştırılmıştır.

$\mathrm{Bu}$ amaçla aşağıdaki sorulara yanıt aranmıştır.

"Aktif öğrenmeye dayalı etkinliklerin okul öncesi öğretmen adaylarının;

1.çevre etiğine ilişkin farkındalıkları,

2.çevreye ilişkin davranışları, 
3.çevre eğitimi özyeterlikleri

üzerinde etkisi var mıdır?

\section{Yöntem}

Araştırmada karma araştırma desenlerinden zenginleştirilmiş desen (triangulation design) esas alınmıştır. Zenginleştirilmiş desende nitel ve nicel veriler eş zamanlı olarak toplanarak verilerin birbirlerini destekleyip desteklemediklerine bakılmaktadır (Büyüköztürk, KılıçÇakmak, Akgün, Karadeniz ve Demirel, 2017,s.266). Yapılan araştırmada da nicel ve nitel veriler birlikte toplanarak nicel veriler nitel verilerle desteklenmiştir. Nicel araştırma bulguları için zayıf deneysel desen dikkate alınarak araştırma gerçekleştirilmiştir. Büyüköztürk ve diğ. (2017, s.209)'ne göre zayıf deneysel desenlerde denek temelinde seçkisizlik ve grup eşleştirmesi yoktur. Bu çalışmada kontrol grubu bulunmadığı ve dolayısıyla tek gruplu olduğu, ayrıca çalışma grubu araştırmacılardan birinin çalıştığg kurumda olduğu ve dolayısıyla temelde seçkisizlik ilkesi uygulanmadığı için zayıf deneysel desen olarak belirlenmiştir.

\section{Çalışma grubu}

Araştırma 2017-2018 eğitim öğretim yılında Gaziantep’te bir üniversitede ikinci sınıfta öğrenim gören okulöncesi öğretmen adayları $(n=30)$ ile yapılmıştır. Ancak bir öğretmen adayının verileri, eksik veri içermesi nedeniyle değerlendirmeye alınmamış ve ikisi erkek, 27'si kadın 29 kişiye ilişkin verilerle araştırma yürütülmüştür. Öğretmen adaylarının yaşları 18-20 yaş aralığında olup sadece bir kadın aday 40 yaş üzerindedir.

\section{Veri toplama araçları}

Araştırma kapsamında okulöncesi öğretmen adaylarından veri elde etmek üzere üç ayrı ölçek ön test ve son test olarak uygulanmıştır. Ölçekler, öğretmen adaylarına 14 haftalık eğitim sürecinin başında ve sonunda araştırmacılardan biri tarafından uygulanmıştır. Ayrıca ölçekler dışında öğretmen adaylarının ders kapsamında hazırladıkları film inceleme sunumları, makale inceleme sunumları ve çevreye ilişkin etkinlik sunumları değerlendirilerek nitel veriler de toplamıştır. Öğretmen adaylarına araştırmacılardan biri tarafından araştırmanın ilk 2 haftasında çevreye ilişkin temel kavramlar, insan çevre ilişkisi, sürdürülebilirlik ve okul öncesi dönemde çevre eğitimi konusunda genel bilgi verilmiş daha sonra uygulama kapsamında öğretmen adayları tarafından hazırlanan aktif öğrenmeye dayalı etkinlikler sunulmuştur. Tablo 1 süreci özetlemek amaciyla oluşturulmuştur.

Tablo1:

Araştırma Süreci

\begin{tabular}{cccccc}
\hline 1.HAFTA & 1-2. HAFTA & 3-7. HAFTA & 8-9. HAFTA & 10-14. HAFTA & 14. HAFTA \\
\hline Ön test Uygulama & $\begin{array}{c}\text { Çevreye İlişkin } \\
\text { Temel Kavramlar }\end{array}$ & $\begin{array}{c}\text { Çevre Film } \\
\text { İnceleme Ödev } \\
\text { Sunumları }\end{array}$ & $\begin{array}{c}\text { Makale İnceleme } \\
\text { Ödev Sunumları }\end{array}$ & $\begin{array}{c}\text { Çevreye İlişkin } \\
\text { Hazırlanan } \\
\text { Etkinliklerin Sunumu }\end{array}$ & $\begin{array}{c}\text { Son test } \\
\text { Uygulama }\end{array}$ \\
\hline
\end{tabular}


Çevre Davranış Ölçeği (ÇDA): Orijinali Goldman, Yavetz ve Pẻer (2006) tarafından geliştirilmiş, Timur ve Yılmaz (2013) tarafından Türkçeye uyarlanmıştır. Ölçek beşli likert tipinde (hiçbir zaman-her zaman) 6 alt boyuttan ve 20 maddeden oluşmaktadır. Her bir alt boyut için cronbach alfa değerleri "Kişinin Ekonomik Yararına Olan Kaynak Koruma Aktiviteleri (Keyokka)" alt boyutunda 0.68, "Çevreye Duyarlı Tüketici (Çdt)" alt boyutunda 0.66, "Doğa İle İlgili Boş Zaman Aktiviteleri (Dibza)" alt boyutunda 0.70, "Geri Dönüşüm Çabaları (Gdç)" alt boyutunda 0.63, "Sorumlu Vatandaşlık (Sv)" alt boyutunda 0.68, "Çevre Eylemciliğii(Çe)" 0.57 olarak bulunmuştur. Ölçeğin tümü için hesaplanan Cronbach’s Alpha güvenirlik katsayısı 0.85 'dir. Yapılan araştırmada ise ön testte güvenirlik katsayısı 0.79 , son testte ise 0.88 olarak hesaplanmıştır.

Çevre Etiği Farkındalık Ölçeği(ÇEF): Özer (2015) tarafından geliştirilen ölçek 23 maddeden ve dört faktörden oluşmaktadır. Her bir alt boyut için cronbach alfa değerleri "ç̧evre etiğinin tanımı" 0.92 ; "çevre etiğinin amacı" 0.675 , "çevre etiğinin ortaya çıkış nedenleri" 0.823 ve "çevre etiğine yönelik alınacak önlemler" için de 0.902 olarak bulunmuştur. Ölçeğin geneli için ise cronbach alfa katsayısı 0.95 olarak bulunmuştur. Ölçek beşli likert tipte kesinlikle katılıyorum-kesinlikle katılmıyorum şeklinde hazırlanmıştır. Ölçekten alınabilecek maksimum puan 115’tir. Yapılan araştırmada ise ön testte güvenirlik katsayısı 0.84 , son testte ise 0.90 olarak hesaplanmıştır.

Çevre Eğitimi Özyeterlik Ölçeği (ÇÖZ): Özlü (2012) tarafından geliştirilen ölçek 24 maddeden ve 2 alt boyuttan oluşmaktadır. Her bir alt boyut için cronbach alfa değerleri "alan bilgisi” boyutu 0.93 ve "öğretim stratejileri”" 0.96 olarak bulunmuştur. Ölçeğin geneli için cronbach a katsayısı 0.97 olarak bulunmuştur. Ölçeğin ölçeklendirmesi 0-100 arasında yapılmıştır. Yapılan araştırmada ise ön testte güvenirlik katsayısı 0.90 , son testte ise 0.96 olarak hesaplanmıştır.

\section{Işlem}

Öğretmen adayları ders kapsamında ilk olarak çevreye ilişkin 18 adet filmi bireysel ya da iki kişilik gruplar halinde inceleyerek 15 dakikalık kısa filmler haline getirmişlerdir. Bu kısa filmleri tüm öğretmen adayları ile izledikten sonra filmde geçen çevre kavramlarını ya da olaylarını eleştirel bir gözle inceleyerek sınıfta tartı̧̧ışlardır. Öğretmen adayları filmleri kendilerine sunulan liste içerisinden seçerek hazırlamışlardır. Bu listede yer alan filmlerin bir kısmı belgesel, bir kısmı animasyon film ve diğerleri ise sinema filmi şeklindedir. Öğretmen adayları liste içerisinden her birinden 6 tane olmak üzere kendi istekleriyle eşit dağılımla film seçmişlerdir. Öğretmen adaylarının seçtikleri film konuları; hidroelektrik santraller ve çevreye etkileri, nükleer enerji ve etkileri, toprak ve su kirliliği, nesli tükenen hayvanlar ve geri dönüşüm ile ilgilidir. Öğretmen adaylarının film ve içeriğindeki çevreye ilişkin olaylara yönelik hazırladıkları ödevler, teknik ve içerik unsurlar yönünden değerlendirilmiştir. Teknik unsurların içerisinde örneğin film hakkında genel bilgi verilme durumu, filmin süresine uygun kısaltılması, gerekli hazırlıkların tamamlanması gibi başlıklar bulunmaktadır. İçerik açısından ise film; çevreye ilişkin filmde geçen kavramların tespit edilme ve açılanma durumu, filmdeki çevre konusunun eleştirel aktarılması, neden ve sonuçlarının, avantaj ya da dezavantajlarının tartışılması, eğitim amaçlı nasıl kullanılabileceğinin belirtilmesi/tartışılması vb. yönünden değerlendirilmiştir. Araştırma kapsamında yapılan uygulamalardan elde edilen nitel verilerin bir kısmı nicel verileri açıklamada 
kullanılmıştır. Örneğin araştırmanın amacı kapsamında olmayan filme ilişkin teknik unsurlara bulgularda yer verilmemiş ancak araştırmanın amacı doğrultusunda içerik açısından yapılan değerlendirmelere nitel veri olarak yer verilmiştir. Öğretmen adaylarından film sunumlarına ilişkin yazılı bir ödev de araştırmacılar tarafından hazırlanan şablona uygun şekilde hazırlanması istenerek toplanmıştır. Bu yazılı ödevler alan uzmanı araştırmacılar tarafından incelenmiştir.

Öğretmen adayları daha sonra okul öncesi dönem için çevreye yönelik yapılan bilimsel makale ya da tezleri incelemişlerdir. Öğretmen adayları inceledikleri bu bilimsel çalışmalar içerisinden iki tanesini seçerek sınıf ortamında diğer adaylara sunmuşlardır. Bu sunumlarda; çalışmanın amacı, yöntemi, eğer uygulama içeriyorsa bu uygulamalarda yapılan işlemler, bulgular, sonuç ve öneriler yer almıştır. Öğretmen adaylarının yaptıkları bu araştırma ödevi ile hem alanda yapılan çalışmaları ve uygulamaları görerek incelemeleri hem de çevreye yönelik etkinlik planlamalarına ve bu kapsamda yapacakları ders sunumlarına hazırlık yapmaları da sağlanmaya çalışılmıştır. Araştırmanın bu kısmında da çevre film sunumlarında olduğu gibi öğretmen adaylarının sunumları bilimsel çalışmaların teknik ve içerik olarak ve değerlendirilmesine yönelik maddeler bulundurmaktadır. Benzer şekilde öğretmen adaylarının inceledikleri bilimsel çalışmaların içerikleri uygulama unsurları açısından değerlendirilerek araştırmanın amacı doğrultusunda nitel verilere yer verilmiştir. Öğretmen adaylarının sunumlarına yönelik içerikleri yazılı ödev olarak da teslim alınmış ve incelenmiştir.

Öğretmen adayları ders kapsamında son olarak öğretim programlarını baz alarak okul öncesi dönemde öğrencilere yaptırabilecekleri çevreye yönelik etkinlikleri tasarlamış ve sınıf ortamında sunmuşlardır. Tasarlanan bu etkinlikler benzer şekilde yazılı ödev olarak da teslim edilmiştir. Etkinlikler ayrıca video kaydı alınarak gerekli görüldüğü durumlarda tüm araştırmacılar tarafından amaca yönelik olarak izlenmiştir. Öğretmen adaylarının ders sunumları etkinliğin özgün, ilgi çekici olması, yaş dönemine uygun olması, çevre kavramlarının doğru ifade edilmesi, seçilen kazanımın niteliği (davranış-bilgi kazandırma), öğrenci katılımını esas alan etkinlik tasarlama, konuyu yaşamla ilişkilendirme, çevreye ilişkin hangi konuların işlendiği vb. yanı sıra sunumlarının etkililiği açısından da değerlendirilmiştir. Yine benzer şekilde araştırmanın amacı kapsamında nitel verilere bulgularda yer verilmiştir.

\section{Verilerin analizi}

Bireylerin ÇDA, ÇEF ve ÇÖZ ölçeklerinden aldıkları puanlara ilişkin betimsel istatistikler tepe değer, ortanca, aritmetik ortalama, standart sapma, en küçük ve en büyük değerler üzerinden incelenmiştir. Deneysel işlem öncesinde ÇDA, ÇEF ve ÇÖZ ölçeklerinin her bir faktöründen ve toplamından alınan puanlar (ön test) ile deneysel işlemden sonraki uygulamadan alınan puanlar (son test) arasındaki farkların manidarlığı, varsayımlarının karşılandığı durumlarda parametrik bir test olan ilişkili ölçümler için t testi ile; varsayımların karşılanmadığı durumlarda ise Wilcoxon işaretli sıralar testi ile incelenmiştir. Ön test ve son test puanları arasındaki farkın manidar olduğu durumlarda etki büyüklügü Cohen $\mathrm{d}$ üzerinden incelenmiş ve $0.2,0.5,0.8$ değerleri sırasıyla küçük, orta ve yüksek etki büyüklügüünü göstergesi olarak yorumlanmıştır (Cohen, 1992). İstatistiksel analizlerde manidarlık düzeyi olarak 0.05 esas alınmıştır. Nitel veriler 
ise öğrencilerin çevre etiği farkındalığı, çevre davranışı ve çevre eğitimine ilişkin özyeterlikleri bağlamında nicel verileri açıklamak için örnek ifadelerle betimsel olarak çözümlenmiştir.

\section{Bulgular}

Araştırma kapsamında 29 kişilik okul öncesi öğretmen adayı grubuna deneysel işlemden önce (ön test) ve sonra (son test) uygulanan ÇDA, ÇEF ve ÇÖZ ölçeklerinden elde edilen verilere ilişkin betimsel istatistikler Tablo 2'de verilmiştir.

Tablo 2.

ÇDA, ÇEF ve ÇÖZ Verilerine İlişkin Betimsel İstatistikler

\begin{tabular}{|c|c|c|c|c|c|c|c|c|}
\hline Ölçüm & Ölçek & Alt boyut & Tepe değer & Ortanca & Ortalama & Standart sapma & Min & Maks \\
\hline \multirow{15}{*}{ Ön test } & \multirow{7}{*}{$\mathrm{ÇDA}^{*}$} & Keyokka & 11 & 11 & 10.79 & 1.14 & 9 & 15 \\
\hline & & Çdt & 13 & 12 & 12.03 & 1.57 & 9 & 15 \\
\hline & & Dibza & 13 & 13 & 12.90 & 2.91 & 7 & 19 \\
\hline & & $\mathrm{Gd} c ̧$ & 11 & 10 & 9.52 & 2.78 & 3 & 14 \\
\hline & & Sv & 11 & 12 & 12.45 & 1.70 & 5 & 21 \\
\hline & & Çe & 2 & 3 & 3.55 & 1.70 & 2 & 8 \\
\hline & & ÇDA Toplam & 63 & 63 & 61.24 & 8.83 & 46 & 85 \\
\hline & \multirow{5}{*}{$\mathrm{CCEF}^{*}$} & Tanım & 35 & 34 & 33.59 & 2.04 & 28 & 35 \\
\hline & & Amaç & 15 & 15 & 14.59 & .87 & 12 & 15 \\
\hline & & Neden & 25 & 24 & 22.59 & 2.56 & 17 & 25 \\
\hline & & Önlem & 38 & 37 & 36.21 & 3.20 & 28 & 40 \\
\hline & & ÇEF Toplam & 113 & 109 & 106.96 & 7.27 & 86 & 115 \\
\hline & \multirow{3}{*}{ ÇÖZ* } & Alan & 630 & 710 & 698.83 & 89.35 & 545 & 840 \\
\hline & & Strateji & 700 & 980 & 965.41 & 154.10 & 700 & 1235 \\
\hline & & ÇÖZ Toplam & 1630 & 1708 & 1664.24 & 231.28 & 1270 & 2075 \\
\hline \multirow{15}{*}{ Son test } & \multirow{7}{*}{ ÇDA } & Keyokka & 11 & 11 & 10.90 & 1.61 & 8 & 15 \\
\hline & & Çdt & 13 & 13 & 12.17 & 2.24 & 5 & 15 \\
\hline & & Dibza & 15 & 14 & 13.50 & 3.16 & 6 & 19 \\
\hline & & $\mathrm{Gd} c ̧$ & 9 & 11 & 10.32 & 2.88 & 3 & 15 \\
\hline & & Sv & 10 & 13 & 13.48 & 4.16 & 5 & 24 \\
\hline & & Çe & 2 & 4 & 4.31 & 2.36 & 2 & 10 \\
\hline & & ÇDA Toplam & 47 & 65 & 64.21 & 13.11 & 39 & 96 \\
\hline & \multirow{5}{*}{ ÇEF } & Tanım & 35 & 35 & 33.03 & 2.83 & 26 & 35 \\
\hline & & Amaç & 15 & 15 & 14.72 & .78 & 12 & 15 \\
\hline & & Neden & 25 & 24 & 22.86 & 2.53 & 16 & 25 \\
\hline & & Önlem & 40 & 37 & 36.24 & 3.92 & 27 & 40 \\
\hline & & ÇEF Toplam & 115 & 109 & 106.86 & 8.33 & 83 & 115 \\
\hline & \multirow{3}{*}{ ÇÖZ } & Alan Bilgisi & 800 & 800 & 777.79 & 133.96 & 355 & 992 \\
\hline & & $\begin{array}{l}\text { Öğretim } \\
\text { Stratejileri }\end{array}$ & 990 & 1160 & 1114.86 & 174.96 & 520 & 1390 \\
\hline & & ÇÖZ Toplam & 1670 & 1960 & 1892.66 & 302.41 & 875 & 2382 \\
\hline
\end{tabular}


*ÇDA: Çevre Davranış Ölçeği; "Kişinin Ekonomik Yararına Olan Kaynak Koruma Aktiviteleri (Keyokka), "Çevreye Duyarlı Tüketici (Çdt)", "Doğa İle İlgili Boş Zaman Aktiviteleri (Dibza)”, "Geri Dönüşüm Çabaları (Gdç)”, "Sorumlu Vatandaşılı (Sv)", "Çevre Eylemciliği (Çe); Çevre Etiği Farkındalık Ölçeği (ÇEF); "Çevre etiği tanım (Tanım), Çevre etiğinin amaçları(Amaç), Çevre etiğinin ortaya çıkış nedenleri (Neden), Çevre etiği alınacak önlemler (Önlem); Çevre Eğitimi Özyeterlik Ölçeği (ÇÖZ).

Tablo 2'de verilen değerler incelendiğinde, ÇEF toplam puanları haricindeki aritmetik ortalamaların son test lehine artış gösterdiği görülmektedir. Aritmetik ortalamalar arasındaki bu farkların istatistiksel manidarlığı sınanmadan önce parametrik bir teknik olan ilişkili ölçümler için $t$ testinin varsayımlarının karşılanıp karşılanmadığı incelenmiştir.

Field (2013) ilişkili ölçümler için t testinin uygulanabilmesi için bağımlı değişkene ait puanların en az aralık ölçeğinde olması ve ilişkili iki ölçüm setine ait fark puanlarının normal dağılım göstermesi gerektiğini ifade etmektedir. Büyüköztürk (2016) dağılımın normalliğinin incelenmesinde kişi sayısının 50'den küçük olduğu durumlarda Shapiro-Wilks testinden yararlanılabileceğini belirtmektedir. Fark puanları hesaplanmadan önce, veri setinde Dibza ve Gdc alt ölçeklerinde birer kayıp verinin bulunduğu görülmüş ve kayıp verilerin örüntüsü Little’ın tümüyle seçkisiz kayıp testi (Little’s MCAR test) ile incelenmiştir. İnceleme sonucunda elde edilen test istatistiğinin manidar olmadığı görülmüş ve kayıp verilerin tümüyle seçkisiz kayıp koşulunu sağladığ ${ }_{1}$ görülmüştür $\left(\chi_{52}^{2}=3.82, \mathrm{p}>.05\right)$. Köse ve Öztemur'un (2014) önerileri doğrultusunda kayıp veriler yerine beklenti - maksimizasyon yöntemi ile değer ataması gerçekleştirilmiştir.

Ön test ve son test puanları arasındaki farkların normal dağılım gösterip göstermediğini belirlemek için gerçekleştirilen Shapiro-Wilks testi sonuçları Tablo 3'de verilmiştir.

\section{Tablo 3.}

Fark Puanlarına İlişkin Shapiro-Wilks Testi Sonuçları

\begin{tabular}{cccc}
\hline Ölçek / Faktör & Test istatistiği & Serbestlik derecesi & p \\
\hline Keyokka & .89 & 29 & .00 \\
Çdt & .91 & 29 & .02 \\
Dibza & .93 & 29 & .06 \\
Gdç & .96 & 29 & .30 \\
Sv & .96 & 29 & .34 \\
Çe & .92 & 29 & .03 \\
ÇDA Toplam & .99 & 29 & .99 \\
\hline Tanım & .82 & 29 & .00 \\
Amaç & .66 & 29 & .00 \\
Neden & .94 & 29 & .13 \\
Önlem & .90 & 29 & .01 \\
ÇEF Toplam & .84 & 29 & .00 \\
\hline Alan Bilgisi & .97 & 29 & .66 \\
Öğretim Stratejileri & .97 & 29 & .60 \\
ÇÖZ Toplam & .97 & 29 & .61 \\
\hline
\end{tabular}


ÇDA: Çevre Davranış Ölçeği; “Kişinin Ekonomik Yararına Olan Kaynak Koruma Aktiviteleri (Keyokka), "Çevreye Duyarlı Tüketici (Çdt)", "Doğa İle İlgili Boş Zaman Aktiviteleri (Dibza)" ,"Geri Dönüşüm Çabaları (Gdç)”, "Sorumlu Vatandaşlık (Sv)", "Çevre Eylemciliği (Çe); Çevre Etiği Farkındalık Ölçeği (ÇEF); "Çevre etiği tanım (Tanım), Çevre etiğinin amaçları (Amaç), Çevre etiğinin ortaya çıkış nedenleri (Neden), Çevre etiği alınacak önlemler (Önlem); Çevre Eğitimi Özyeterlik Ölçeği (ÇÖZ).

Tablo 3'de Dibza, Gdç, Sv, ÇDA toplam, çevre etiğinin ortaya çııış nedenleri, alan bilgisi, öğretim stratejileri ve ÇÖZ toplam için elde edilen fark puanlarının dağılımının normal kabul edilebileceği görülmektedir ( $\mathrm{p}>$.05). Dibza, Gdç, Sv, ÇDA toplam, çevre etiğinin ortaya çıkış nedenleri, alan bilgisi, öğretim stratejileri ve ÇÖZ toplam ön test ve son test puanları için gerçekleştirilen ilişkili ölçümleri için t testi sonuçları Tablo 4’te verilmiştir.

Tablo 4.

Dibza, Gdç, Sv, ÇDA Toplam, Neden, Alan, Strateji ve ÇÖZ Toplam Puanları için İlişkili t Testi Sonuçları

\begin{tabular}{cccccccc}
\hline Ölçek / Faktör & Ölçüm & $\mathrm{N}$ & Ortalama & Standart sapma & sd & $\mathrm{t}$ & $\mathrm{p}$ \\
\hline Dibza & Ön test & 29 & 12.90 & 2.91 & 28 & .67 & .51 \\
& Son test & & 13.28 & 3.32 & & & \\
\hline Gdç & Ön test & 29 & 9.52 & 2.78 & 28 & .97 & .34 \\
& Son test & & 10.10 & 3.06 & & & \\
\hline Sv & Ön test & 29 & 12.44 & 3.25 & 28 & 1.80 & .08 \\
& Son test & & 13.48 & 4.16 & & & \\
\hline ÇDA toplam & Ön test & 29 & 61.24 & 8.83 & 28 & 1.74 & .09 \\
& Son test & & 64.21 & 13.11 & & & \\
\hline Neden & Ön test & 29 & 22.59 & 2.55 & 28 & .62 & .54 \\
& Son test & & 22.86 & 2.53 & & & \\
\hline Alan Bilgisi & Ön test & 29 & 698.83 & 89.35 & 28 & 3.37 & $.00^{* *}$ \\
& Son test & & 777.79 & 133.96 & & & \\
\hline Öğretim & Ön test & 29 & 965.41 & 154.10 & 28 & 4.45 & $.00^{* *}$ \\
Stratejileri & Son test & & 1114.86 & 174.96 & & & \\
\hline ÇÖZ toplam & Ön test & 29 & 1664.24 & 231.28 & 28 & 4.19 & $.00^{* *}$ \\
& Son test & & 1892.66 & 302.41 & & & \\
\hline
\end{tabular}

Tablo 4'te Dibza, Gdç, Sv, ÇDA toplam, Neden toplam puanları için ön test ve son test puanları arasındaki farkların manidar olmadığı ( $\mathrm{p}>$.05) ve Alan Bilgisi, Öğretim Stratejileri ve ÇÖZ toplam puanları için ön test ve son test puanları arasındaki farkların ise son test lehine manidar olduğu görülmektedir. Öğretmen adayları inceledikleri filmlerde; geri dönüşüm ve önemi, çevreye ilişkin bireysel olarak vatandaşlık ve görevleri ya da çevreye yönelik olumsuz durumlarda yapılan bireysel faaliyetlerin önemi gibi durumları inceleme şansını elde etmişlerdir. Ayrıca filmlerde geçen konuları çeşitli açılardan tartışmışlardır. Öğretmen adayları filmlerdeki 
çevreyle ilgili durumlara ilişkin avantaj ve dezavantaj yaratabilecek noktaları tartışırken de bu konular üzerinde durmuşlardır. Örneğin ders raporunda bir öğrenci Wall-e filmine ilişkin;

“...çevreye bıraktığımız çöplerin nelere yol açacağını daha iyi öğrendim ve fikrim olmayan bazı noktaları gördüm. Geri dönüşüme ne kadar ihtiyacımız olduğunu anladım...”

şeklinde düşüncesini belirtmiştir. Ayrıca öğretmen adayları inceledikleri bilimsel araştırmalardaki uygulama örneklerinde geri dönüşüm konusunda bilgi ve davranış kazandırmayı hedefleyen örnekler sunmuşlardır. Bununla birlikte çevreye yönelik olumlu davranış ya da algı geliştirmeyi hedefleyen çalışmalara da yer vermişlerdir. Öğretmen adaylarının çevreye ilişkin geliştirdikleri etkinliklerde de geri dönüşüm konusunda kazanımlar seçerek en fazla sayıda etkinliği bu konuda tasarladıkları görülmüştür. Öğretmen adaylarının sekiz tanesi doğrudan geri dönüşüme yönelik etkinlik tasarlamış beş tanesi ise başka etkinlikleri arasında geri dönüşüme yer vermişlerdir. Bir öğretmen adayı, izlediği filmden (Çöplük) etkilenerek geri dönüşüm konusunda etkinlik tasarladığını şöyle belirtmiştir:

“... İzlediğimiz filmlerden bir tanesi beni etkiledi. Daha önce bu kadar yı̆̆ınlar halinde çöpler ve bunlara bağl yaşamlar düşünmemiştim. Hani orada diyorlar ya biz olmasak bunlar nasıl ayrılacak işimiz önemli ben de buna önem verdim. Geri dönüşüm ne kadar iyi yapılırsa ve öğrencilere öğretirsek o zaman çevreye katkımız çok olur. Öğretmen olarak da başarabiliriz bunu..." ÖA7

Öğretmen adaylarının alan bilgisi, öğretim stratejileri ve ÇÖZ toplam puanları son test lehine daha yüksek bulunmuştur ve etki büyüklükleri (Cohen d) sirasıly 0.64, 0.84 ve 0.79 düzeyindedir. Buna göre, deneysel işlemin Öğretim Stratejileri üzerinde yüksek; Alan Bilgisi ve ÇÖZ toplam puanları üzerinde ise orta düzey bir etkisinin olduğu söylenebilir. Öğretmen adayları aktif öğrenmeye dayalı olarak gerçekleştirilen etkinliklerde bilimsel çalışmaları araştırırken çevre konularını öğretmeye yönelik uygulamaları detaylı inceleme şansı elde etmişlerdir. Öğretmen adayları ders sunumları yaparak çevreye ilişkin kendi etkinliklerini geliştirme olanağına da sahip olmuşlardır. Bu sunumlar için çeşitli öğretim stratejilerini uygulamışlardır. Ayrıca öğretmen adayları izledikleri filmlerdeki unsurları dersleriyle nasıl ilişkilendirebileceklerini de film sunumları sırasında tartışmışlardır. Öğretmen adayları taradıkları bilimsel çalışmalardan en az bir tanesini uygulama içerecek şekilde sunmuşlar ve uygulamaların nasıl ve ne amaçla yapıldığını detaylı şekilde açıklamışlardır. Ayrıca öğretmen adayları çeşitli eğitsel oyunlar, deneyler, davranış geliştirici uzun soluklu uygulamalar tasarlayarak farklı öğretim yöntemleristratejileri uygulayabilmiş ve birbirlerinden de farklı yaş grupları için etkinlik örnekleri görme şansına erişmişlerdir. Öğretmen adaylarının hazırladıkları davranış geliştirmeyi destekleyen etkinliklerin sürelerinin bir dönemden bir yıla kadar değişen aralıklarda olduğu görülmüştür. Öğretmen adaylarının dört tanesi bu tür etkinlikler tasarlayarak etkinlikleri sırasında davranış kazandırmanın uzun soluklu bir iş olduğunun farkında olduklarını göstermişlerdir. Öğretmen adaylarından bir tanesi etkinliği ile ilgili olarak; 
“...etkinliğim bir yıl boyunca sürecek. Öğrencilerin yaptıkları işi anlamaların ve sürdürmelerini istiyorum. Bir kere olursa unuturlar. Ayrıca aileleri de önemli onlar da işin içinde olacaklar..."

şeklinde hem etkinliğinin amacını belirtmiş hem de ailelerin rolünü unutmayarak aile katılımının gerekliliğini vurgulamıştır.

Keyokka, Çdt, Çe, Çevre Etiğinin Tanımı, Çevre Etiğinin Amacı, Çevre Etiği Alınacak Önlemler ve Çef toplam ön test ve son test puanları arasındaki farkın manidarlığı Wilcoxon işaretli sıralar testi ile incelenmiştir. Wilcoxon işaretli sıralar testi sonuçları Tablo 5’te verilmiştir.

\section{Tablo 5.}

Keyokka, Çdt, Çe, Tanım, Amaç, Önlem ve Çef Toplam Puanları için Wilcoxon Testi Sonuçları

\begin{tabular}{|c|c|c|c|c|c|c|}
\hline Ölçek / Faktör & Ölçüm & $\mathrm{N}$ & Sira Ortalamas1 & Sıra Toplamı & $\mathrm{Z}^{\mathrm{g}}$ & $\mathrm{p}$ \\
\hline \multirow{3}{*}{ Keyokka } & Negatif & 8 & 6.81 & 54.50 & .32 & .75 \\
\hline & Pozitif & 7 & 9.36 & 65.50 & & \\
\hline & Eşit & 14 & & & & \\
\hline \multirow{3}{*}{ Çdt } & Negatif & 7 & 14.93 & 104.50 & .39 & .70 \\
\hline & Pozitif & 14 & 9.04 & 126.50 & & \\
\hline & Eşit & 8 & & & & \\
\hline \multirow{3}{*}{ Çe } & Negatif & 7 & 10.86 & 76.00 & 1.67 & .10 \\
\hline & Pozitif & 15 & 11.80 & 177.00 & & \\
\hline & Eşit & 7 & & & & \\
\hline \multirow{3}{*}{ Tanım } & Negatif & 9 & 11.39 & 102.50 & .75 & .45 \\
\hline & Pozitif & 9 & 7.61 & 68.50 & & \\
\hline & Eşit & 11 & & & & \\
\hline \multirow{3}{*}{ Amaç } & Negatif & 2 & 4.50 & 9.00 & .86 & .40 \\
\hline & Pozitif & 5 & 3.80 & 19.00 & & \\
\hline & Eşit & 22 & & & & \\
\hline \multirow{3}{*}{ Önlem } & Negatif & 9 & 12.89 & 116.00 & .67 & .50 \\
\hline & Pozitif & 14 & 11.43 & 160.00 & & \\
\hline & Eşit & 6 & & & & \\
\hline \multirow{3}{*}{ ÇEF toplam } & Negatif & 11 & 16.18 & 178.00 & .57 & .57 \\
\hline & Pozitif & 17 & 13.41 & 228.00 & & \\
\hline & Eşit & 1 & & & & \\
\hline
\end{tabular}

gNegatif sira.

Tablo 5’te de görüldüğü üzere Keyokka, Çdt, Çe, Tanım, Amaç, Önlem ve ÇEF toplam puanları için ön test ve son test puanları arasında manidar bir fark bulunmamıştır (p>.05).

Çevre Davranış Ölçeğininin Kişinin Ekonomik Yararına Olan Kaynak Koruma Aktiviteleri (Keyokka), Çevreye Duyarlı Tüketici (Çdt), Çevre Eylemciliği (Çe) alt boyutları incelendiğinde 
öğretmen adaylarının çalışma kapsamında bu boyutlara ilişkin kısıtlı sayıda etkinlik gerçekleştirdikleri görülmektedir. Öğretmen adaylarının seçtiği filmlerden bir tanesi Kişinin Ekonomik Yararına Olan Kaynak Koruma Aktiviteleri (Keyokka), iki tanesi Çevreye Duyarlı Tüketici (Çdt) ve başka 2 tanesi Çevre Eylemciliği (Çe) konularını içeren unsurlar taşımaktadır. Bilimsel çalışma ödevlerinde ise bu alt boyutlarda hiç çalışmaya ulaşamadıkları görülmüştür. Az sayıda öğretmen adayının tasarladıkları etkinliklerde de bu konulara değindikleri görülmüştür. Sadece bir öğretmen adayı kendi tasarladığı etkinlikte gazete kâğıtlarından kese kâğıdı yapılarak bunların kullanımı konusuna ve iki öğretmen adayı su tasarrufu konusuna yer vermiştir. Ayrıca öğretmen adaylarının bu alt boyutlardaki ön test ve son test ortalama puanları incelendiğinde (Keyokka:10,79-10,90; Çdt:12,03-12,17) adayların ortalama puanlarının genel olarak ölçekten alınabilecek maksimum puana göre yüksek olduğu görülmektedir. Çevre eylemciliği (Çe:3,554,31) alt boyutunda da benzer şekilde ön test ve son test puanları arasında çok farklılık olmadığı ve ölçekten alınabilecek maksimum puana göre orta düzeyde olduğu görülmektedir.

Öğretmen adaylarının ön test $(106,96)$ ve son test $(106,86)$ ortalama puanları ve ölçekten alınabilecek maksimum puan incelendiğinde öğretmen adaylarının çevre etiğine ilişkin farkındalıklarının ön testte zaten yüksek olduğu ve son testte de değişmediği görülmektedir. Öğretmen adaylarından üç tanesi hazırladıkları etkinliklerde doğal dengenin korunabilmesi ve insanların çevreye zarar vermeden üretim yapabilmeleri için basit bazı önlemler alınabileceğini belirtmişlerdir.

Bu kapsamda doğal gübre yapımı ve böceklerin doğal yollarla bitkilere zarar vermesinin engellenmesine yönelik, öğrencilerinin yaş gruplarına uygun ve yapım aşamalarını da içeren etkinlikler tasarlamışlardır. Gübre için gerekli maddelerin öğrencileri tarafından temin edilmesini ve bu sürecin birkaç ay sürecek şekilde yapılmasını da planlamış ve etkinliklerinde bu ayrıntılara da yer vermişlerdir.

Öğretmen adaylarından on iki tanesi 3-4 yaş grubu öğrencilere yönelik etkinlik tasarlarken on yedi tanesi 5 yaş grubuna yönelik tasarım gerçekleştirmiştir. Öğretmen adaylarının etkinlik tasarlarken genellikle 5 yaş grubu öğrencilere yönelik etkinlikleri daha fazla sayıda hazırladıkları görülmüştür. Daha küçük yaş grupları için etkinlik tasarlarken genellikle bilgi kazandırmayı hedefleyen etkinliklere yöneldikleri görülmüştür.

\section{Tartışma, Sonuç ve Öneriler}

Araştırma bulguları incelendiğinde aktif öğrenmeye dayalı yürütülen etkinliklerin okul öncesi öğretmen adaylarının Dibza (Doğa İle İlgili Boş Zaman Aktiviteleri), Gdç (Geri Dönüşüm Çabaları), Sv (Sorumlu Vatandaşlık), ÇDA (Çevre Davranış Ölçeği) toplam, çevre etiğinin ortaya çıkış nedenleri toplam puanları için ön test ve son test puanları arasında manidar fark yaratmadığı bulunmuştur. Ancak Alan Bilgisi, Öğretim Stratejileri ve ÇÖZ (Çevre Eğitimi Özyeterlik) toplam puanları için ön test ve son test puanları arasındaki farkların son test lehine manidar olduğu görülmektedir. Öğretmen adayları inceledikleri filmlerde geri dönüşüm ve önemi, çevreye ilişkin bireysel olarak vatandaşlık ve görevleri ya da çevreye yönelik olumsuz durumlarda yapılan 
bireysel faaliyetlerin önemi gibi durumları görme ve gerçek hayatla ilişkilendirerek üzerlerine ne gibi sorumluluklar alabileceklerinin farkına varabilecekleri durumlarla karşılaşmışlardır. Bunun sonucunda son test verilerinde sorumlu vatandaşlı ve geri dönüşüm konusunda manidar bir fark yaratmasa da toplam puanlarında artış görüldüğü düşünülmektedir. Ayrıca öğretmen adaylarının inceledikleri bilimsel çalı̧malardaki çevre konularını öğretmeye yönelik uygulamaları detaylı inceleme şansları olması ve ders sunumları yaparak çevreye ilişkin kendi etkinliklerini geliştirmeleri ve izledikleri filmlerdeki unsurları dersleriyle nasıl ilişkilendirebileceklerinin tartışılması; özellikle animasyon filmlerin hangi yaş gruplarına çevreye ilişkin hangi durumları öğretmede kullanılabileceğinin tartışlarak işlenmesiyle de ilgili olduğu düşünülmektedir. Ayrıca öğretmen adayları çeşitli eğitsel oyunlar, deneyler, davranış geliştirici uzun soluklu uygulamalar tasarlayarak farklı öğretim yöntemleri-stratejileri uygulayabilmiş ve birbirlerinden de farklı yaş grupları için etkinlik örnekleri görerek bu konudaki özyeterliklerini geliştirme olanağı bulabilmişlerdir. Ders süresince uygulamaların daha ağılıklı olması nedeniyle çevreye ilişkin özyeterlik konusunda öğretmen adaylarının alan bilgisinden ziyade öğretim stratejileri konusunda kendilerini daha fazla geliştirdiklerini düşündükleri söylenebilir. Zayimoğlu-Öztürk, Öztürk ve Şahin (2015)'in yaptıkları araştırmada sınıf öğretmen adaylarının çevre eğitimi dersini alma durumlarının ÇÖZ etkilemediğini ancak alanların daha yüksek puanı olduğunu bulmuşlar ve etkin çevre eğitimi dersine vurgu yapmışlardır. Yapılan araştırmada öğretmen adaylarıyla aktif öğrenme merkezli yürütülen dersin ÇÖZ puanlarında son test lehine fark yarattığ tespit edilmiştir. Şenel (2010) ve Şahin, Cerrah, Saka ve Şahin (2004) tarafından öğretmen adaylarıyla yürütülen araştırmalarda da aktif öğrenme merkezli yürütülen çevre derslerinin çevre bilincinin gelişmesine katkı sağladığı bulunmuştur. Buradan hareketle aktif öğrenme merkezli çevre derslerinin öğretmen adaylarının çevreye yönelik bazı alanların gelişimi üzerinde etkili olduğu söylenebilir. Ayrıca alan yazında yapılan birçok çalışmada Çevre Bilim vb. derslerin farklı alanlardan öğretmen adaylarının çevreye ilişkin çeşitli değişkenler (tutum, çevre etiği, çevre bilinci vb.) üzerinde gelişime katkı sağlamadığı bulunmuştur ve bu tür derslerin içeriğinin gözden geçirilmesi konusunda öneriler getirilmiştir (Bülbül, 2013; Deniş ve Genç, 2007). Bu açıdan aktif öğrenmeye dayalı çevre derslerinin öğretmen adaylarının gelişimi için önemli olduğu görülmektedir.

Öğretmen adaylarının inceledikleri bilimsel araştırmalardaki uygulama örneklerinde geri dönüşüm konusunda bilgi ve davranış kazandırmayı hedefleyen örnekler sunmuşlar ve çevreye ilişkin geliştirdikleri etkinliklerde de geri dönüşüm konusuna sıkça yer vermişlerdir. $\mathrm{Bu}$ bulgulara dayalı olarak okul öncesi dönemde çevreye karşı sorumlu vatandaşlık ve geri dönüşüm konusunda yapılacak etkinliklerle öğrencilerde davranış oluşturulabileceğinin önemini kavradıkları düşünülmektedir. Dolayısıyla öğretmen adaylarının Dibza (Doğa İle İlgili Boş Zaman Aktiviteleri), Gdç (Geri Dönüşüm Çabaları), Sv (Sorumlu Vatandaşlık), ÇDA (Çevre Davranış Ölçeği) toplam verileri arasında ön test ve son test arasında manidar bir fark yaratmasa da ortalama puanları açısından fark oluştuğu düşünülmektedir.

Öğretmen adaylarının çevre etiği farkındalıklarına aktif öğrenmeye dayalı etkinliklerin fark yaratmadığı bulunmuştur. Ön test ve son test ortalama puanları ve ölçekten alınabilecek 
maksimum puanlar öğretmen adaylarının ön testte puanlarının zaten yüksek olduğu ve son testte de değişmediği görülmektedir. Bu nedenle yapılan çalışma kapsamında öğretmen adaylarının çevre etiği farkındalıklarında manidar bir fark oluşmadığı görülmektedir. Bülbül (2013) tarafından çevre etiği algılarında Çevre Bilim dersinin fark yaratmadığı bulunmuştur. Çolak (2017) fen bilgisi öğretmen adaylarının çevre etiği farkındalıklarını yapılan araştırma bulgularını destekler şekilde yüksek olarak bulmuştur.

Öğretmen adaylarının Çevre Davranış Ölçeği’nin Kişinin Ekonomik Yararına Olan Kaynak Koruma Aktiviteleri (Keyokka), Çevreye Duyarlı Tüketici (Çdt), Çevre Eylemciliği (Çe) alt boyutlardaki ön test ve son test ortalama puanları incelendiğinde ortalama puanlarının genel olarak ölçekten alınabilecek maksimum puana göre yüksek olduğu görülmektedir. Çevre eylemciliği alt boyutunda da benzer şekilde ön test ve son test puanları arasında çok farklılık olmadığı ve ölçekten alınabilecek maksimum puana göre orta düzeyde olduğu görülmektedir. Ayrıca araştırma kapsamında öğretmen adaylarının yaptıkları etkinlikler de göz önüne alındığında belirtilen boyutlarda adayların çevreye yönelik davranışlarında yapılan çalışmanın değişiklik yaratmadığı düşünülmektedir. Altınöz (2010) fen bilgisi öğretmen adaylarının çevresel davranışlarının düşük düzeyde olduğunu, Güven ve Aydoğdu (2012) ise orta düzeyde olduğunu tespit etmişlerdir. Davranış geliştirme sürecinin uzun vadeli bir süreç olduğu ve aynı zamanda birçok faktörden etkilendiği düşünülürse öğretmen adaylarının çevreye yönelik davranışlarında yapılan araştırmanın etkili olmamış olabileceği düşünülmektedir.

Öğretmen adaylarının genellikle 5 yaş grubu öğrenciler için etkinlik tasarlamalarının nedeninin öğretmen adaylarının henüz ikinci sınıf olması ve daha küçük yaş grupları için tasarım konusunda zorlanmaları olduğu düşünülmektedir. Yaş grubu küçüldükçe etkinlik bulma konusunda zorlandıkları ve daha çok bilgi kazandırmaya yöneldikleri görülmektedir.

Araştırma bulgularına dayalı olarak bundan sonraki araştırmalarda çevreye yönelik davranışın değiştirilmesine yönelik uzun vadeli çalışmalar yapılabilir. Öğretmen adaylarının aktif öğrenme süreçlerinde gerçekleştirdikleri eylemlerin niteliklerini de inceleyen araştırmalar planlanabilir. Çevreye ve eğitimine yönelik tasarlanan ders içerikleri farklı yaklaşımlarla uygulanarak sonuçları tartışılabilir. Uzun soluklu bir öneri olarak; aktif öğrenmeyle çevre eğitimi alan öğretmen adaylarının mesleklerini icra ederken kullandıkları öğretme yaklaşımlarının incelenmesi ve öğrencilerindeki farklı çevre bileşenlerine etkisi araştırılabilir. Ayrıca okul öncesi döneme ilişkin uygulama ve teoriyi bir arada sunan kaynakların olması öğretmen ve öğretmen adaylarının daha nitelikli uygulamalar geliştirmelerine olanak sağlayacak ve alandaki eksiklerin giderilmesine katkı sunacaktır.

\section{Kaynaklar}

Akkoyunlu Ertan, K. (1998). Çevre etiği. Amme İdaresi Dergisi http://www.todaie.edu.tr/resimler/ ekler/66fc4e7dedc9e51_ek.pdf?dergi=Amme\%20Idaresi\%20. Erişim: 19.02.2018.

Altınöz, N. (2010). Fen bilgisi öğretmen adaylarının çevre okuryazarlık düzeyleri. (Yayımlanmamış YL Tezi). Sakarya Üniversitesi, Sakarya. 
Aydede Yalçın,Y.,M,N. (2016). The effect of active learning based science camp activities on primary school students' opinions towards scientific knowledge and scientific process skills. International Electronic Journal of Environmental Education, 6(2),108-125.

Aydın, N. (2008). Sınıf öğretmeni adaylarının ve öğretmenlerinin çevre eğitimine yönelik öz-yeterlik inançları üzerine sınıf düzeyi, kıdem ve değer yönelimlerinin etkisi. (Yayımlanmamış Yüksek lisans Tezi) Adnan Menderes Üniversitesi, Aydın.

Bandura, A. (1986). Social foundations of thought and action:A social cognitive theory. Englewood Cliffs, N.J.Prentice -Hall.

Bozkurt, O. (2009). Çevre Eğitimi, Editör: Aydoğdu, M., Gezer, K. Çevre Bilimi (4.Baskı). Anı Yayıncılık: Ankara.

Bülbül, S. (2013). Fen Bilgisi Öğretmen Adaylarının Çevre Etiği Algıları Üzerine Bir Araştırma, (Yayımlanmamı̧ Yüksek Lisans Tezi), Gazi Üniversitesi, Ankara.

Büyüköztürk, Ş. (2016). Sosyal bilimler için veri analizi el kitabı: istatistik, araştırma deseni, SPSS uygulamaları ve yorum (22. baskı). Pegem Akademi: Ankara.

Büyüköztürk, Ş., Kılıç-Çakmak,E., Akgün Ö.E., Karadeniz,Ş., Demirel,F. (2017). Bilimsel araştırma yöntemleri (23.baskı). Pegem Akademi: Ankara.

Cohen, J. (1992). A power primer. Psychological Bulletin, 112(1), 155-159.

Çolak, M. (2017). Fen Bilgisi Öğretmen Adaylarının Biyoteknoloji Uygulamalarına Yönelik Tutumları İle Çevre Etiği Farkındalıkları Arasındaki İlişki. 26th International Conference on Educational Sciences, Nisan 20-23, 2017, Antalya. https://www.researchgate.net/publication/322448491_Fen_ Bilgisi_Ogretmen_Adaylarinin_Biyoteknoloji_Uygulamalarina_Yonelik_Tutumlari_Ile_Cevre_ Etigi_Farkindaliklari_Arasindaki_Iliski?enrichId=rgreq-96f0ec6d7f4be00e357d4ebf51bf3bfc-XX X\&enrichSource=Y292ZXJQYWdlOzMyMjQ0ODQ5MTtBUzo1ODIxNDAwOTg0OTg1NjBAM TUxNTgwNDQyMzU3OA\%3D\%3D\&el=1_x_3\&_esc=publicationCoverPdf . erişim: 25.05.2018.

Deniş, H. ve Genç, H. (2007). Çevre bilimi dersi alan ve almayan sınıf öğretmenliği öğrencilerinin çevreye ilişkin tutumları ve çevre bilimi dersindeki başarılarının karşılaştırılması. Mehmet Akif Ersoy Üniversitesi Eğitim Fakültesi Dergisi, 13, 20-26.

Ertan, B. (2004). “2000'li yıllarda çevre etiği yaklaşımları ve Türkiye”, Yönetim Bilimleri Dergisi, 2(1), 93108. http://dergipark.ulakbim.gov.tr/comuybd/article/view/500.003.7419/500.003.6294. erişim: 19.02.2018.

Field, A. (2013). Discovering statistics using IBM SPSS statistics (4th ed.) Sage: London.

Goldman, D., Yavetz, B., and Pe'er, S. (2006). Environmental literacy in teacher training in Israel: Environmental behavior of new students. Journal of Environmental Education, 38(1), 3-22.

Gökmen, A., Ekici, G. ve Öztürk, G., (2012). Biyoloji öğretmen adaylarının çevre eğitimine yönelik özyeterlilik algılarının incelenmesi üzerine bir çalışma, X. Ulusal Fen Bilimleri ve Matematik Eğitimi Kongresi, $\quad$ http://kongre.nigde.edu.tr/xufbmek/dosyalar/tam_metin/pdf/2470-30_05_201221_56_31.pdf erişim: 9.03.2018.

Güven, E., ve Aydoğdu, M. (2012). Çevre Sorunlarına Yönelik Davranış Ölçeğinin Geliştirilmesi ve Öğretmen Adaylarının Davranış Düzeylerinin Belirlenmesi. Uludă̆ Üniversitesi Eğitim Fakültesi Dergisi, 25(2), 573-589.

Kahyaoğlu, M. (2001). Öğretmen Adaylarının Öğrenme Stilleri İle Çevre Eğitimi Öz- Yeterlikleri Arasındaki İlişki. Eğitim Bilimleri Araştırmaları Dergisi, 1(2),67-82.

Kalem, S. ve Fer, S. (2003). Aktif öğrenme modeliyle oluşturulan öğrenme ortamının öğrenme, öğretme ve iletişim sürecine etkisi. Kuram ve Uygulamada Eğitim Bilimleri, 3(2), 433 - 461. http:// 
eds.a.ebscohost.com/eds/detail/detail?vid=0\&sid=0904feb2-aa9e-40d4-a6db-8ce1a3e130a5\%40s essionmgr4008\&bdata=JnNpdGU9ZWRzLWxpdmU\%3d\#AN=11955828\&db=a9h

Köse, İ. A. ve Öztemur, B. (2014). Kayıp veri ele alma yöntemlerinin t-testi ve anova parametreleri üzerine etkisinin incelenmesi. Abant İzzet Baysal Üniversitesi Ĕ̈itim Fakültesi Dergisi, 14(1), 400-412. doi: dx.doi.org/10.17240/aibuefd.2014.14.1-500.009.1519.

Mentiş Taş, A. (2005). Öğretmen eğitiminde aktif öğrenme. Gazi Üniversitesi Kırşehir Eğitim Fakültesi Dergisi, 6(2), 177-184

Önen, F. ve Muşlu Kaygısız,G. (2013). Fen bilgisi öğretmen adaylarının 6-8. dönemler arasındaki fen öğretimine yönelik öz yeterlik inançları ve bu inanca ilişkin görüşleri, Kuram ve Uygulamada Eğitim Bilimleri, 13(4), 2435-2453.

Özer, N. (2015). Fen bilgisi öğretmen adaylarının çevre etiğine yönelik farkındalık düzeylerinin belirlenmesi. (Yayımlanmamış yüksek lisans tezi). Aksaray Üniversitesi, Aksaray.

Pajares, F. (1996). Self-efficacy beliefs in academic settings. Review of Educational Research, 66, 543-578.

Riggs, I. M. \& Enochs, L.G. (1990). Toward the development of an elementary teacher's science teaching efficiacy belief instrument. Science Education, 74(6), 625-637.

Sancar, K., N. (2005). Çevre için halk eğitiminde Japonya ve Türkiye örneği. (Yayımlanmamış Yl Tezi). Ankara Üniversitesi, Ankara.

Süral, S. (2015). Öğretmen Adaylarının Aktif Öğrenmeye Yönelik Algılarının Farklı Değişkenler Açısından İncelenmesi. KSBD, Hüseyin Hüsnü Tekışık Özel Sayısı, 2(7), 31-49.

Şahin, N. F., Cerrah, L., Saka, A., Şahin, B. (2004). Yükseköğretimde öğrenci merkezli çevre eğitimi dersine yönelik bir uygulama. GÜ, Gazi Eğitim Fakültesi Dergisi, 24(3), 113-128.

Şenel, H. (2010). Fen bilgisi öğretmen adaylarının çevre bilincinin geliştirilmesinde probleme dayalı aktif öğrenmenin etkisi.(Yayımlanmamış yüksek lisans tezi). Balıkesir Üniversitesi, Balıkesir.

Timur, S. ve Yılmaz, M. (2013). Çevre Davranış Ölçeğinin Türkçe’ye Uyarlanması. Gazi Üniversitesi Gazi Eğitim Fakültesi Dergisi, 33(2), 317-333.

Tschannen-Moran, M., Woolfolk Hoy, A. \& Hoy, W. K. (1998). Teacher efficacy: Its meaning and measure. Review of Educational Research, 68, 202-248.

Yalçın, C. (1993). Çevre Duyarlılığı ve Eğitimi.(Yayımlanmamış yüksek lisans tezi). Gazi Üniversitesi Sosyal Bilimler Enstitüsü, Ankara.

Yücel Işıldar, G. ve Yıldırım, F. (2008). The effectiveness of environmental education on environmentally- sensitive behaviors. Education and Science, 33(148), 13-25.

Zayimoğlu Öztürk, F., Öztürk, T. ve Şahin, A. (2015). Sınıf öğretmeni adaylarının çevre eğitimi özyeterlik algılarının incelenmesi. Amasya Üniversitesi Eğitim Fakültesi Dergisi, 4(2), 293-311. 